International Journal of

Supply Chain and Logistics

(IJSCL)

DETERMINANTS OF PROCUREMENT OPTIMISATION IN SELECTED COUNTY GOVERNMENTS IN KENYA.

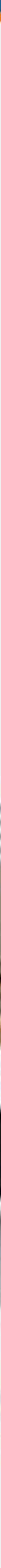




\title{
DETERMINANTS OF PROCUREMENT OPTIMISATION IN SELECTED COUNTY GOVERNMENTS IN KENYA.

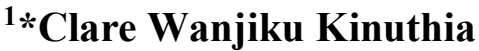 \\ ${ }^{1}$ Post graduate student, Jomo Kenyatta University of Agriculture andTechnology \\ ${ }^{2}$ Dr. Allan Kihara Ph.D. \\ ${ }^{2}$ Lecture, Jomo Kenyatta University of Agriculture andTechnology \\ P. O. Box 62000, 00200 Nairobi, Kenya \\ *Corresponding Author email: kclarewanjiku@gmail.com
}

\begin{abstract}
Purpose: The study was to determine the factors affecting procurement optimization in selected county governments in Kenya with an aim of making recommendations. The study sought to establish the effect of vendor management, risk management, information technology adoption and value for money effect on procurement optimization. To achieve this, the researcher reviewed both theoretical and empirical literature and proposed the research methodology that addressed the gaps identified in literature as well as answer the stipulated research questions. The study employed a descriptive research design.
\end{abstract}

Methodology: The study targeted 136 respondents including the Chief Finance Officers in charge of Finance and Economic Planning, Heads of the Supply Chain Management Unit and Procurement staff at the departmental level. The researcher prefers this method because it allows an in-depth study of the subject. Data was collected using self-administered questionnaires. The target population was the procurement staff at each county government. Pilot study was carried out to establish the validity and reliability of the research instruments. The instruments were designed appropriately according to the study objectives. The data collected were analyzed by use of descriptive and inferential statistics. The study used multiple regression and correlation analysis to show the relationship between the dependent variable and the independent variables. The data generated were keyed in and analyzed by use of Statistical Package of Social Sciences (SPSS) to generate information which was presented using charts, frequencies and percentages.

Results: The study found that vendor managed inventory systems, material resource planning and bar coding of items were deduced to play a significant influence in cost reduction, in lead time reduction and in increasing customer satisfaction. The study concluded that information technology adoption greatest effect on procurement optimization in selected county governments in Kenya followed by vendor management then value for money while risk management had the least effect on the procurement optimization in selected county governments in Kenya in Kenya.

Contribution to policy and practice: The study recommended for the county governments to ensure that there is use inventory management system and automated recording, cycle counting Inventory control; use of E.O.G and that it's important for the county governments to Identify and deal with risks proactively. 
Key Words: Vendor Management, Risk Management, Information Technology Adoption, Value for Money and Procurement Optimization.

\subsection{INTRODUCTION}

Organizations whether for profit or non-profit, private or public have found it necessary in recent years to engage in procurement optimization in order to achieve their corporate goals. The environments in which they operate have become not only increasingly uncertain but also more tightly interconnected. This requires a threefold response from these organizations. They are required to think strategically as never before, need to translate their insight into effective strategies to cope with their changed circumstances and lastly, develop rationales necessary to lay the groundwork for adopting and implementing strategies in this ever-changing environment (Andersen, 2010). Procurement optimization is a unifying theme that gives coherence and direction to the actions and decisions of an organization. It guides an organization to superior performance by helping establish competitive advantage. It acts as a vehicle for communication and coordination within the organization. The goal of strategic management therefore is to build and maintain sustainable competitive advantage and create stakeholders' wealth. Procurement optimization process includes formulation, implementation, evaluation and control (Chandler, 2012). Chandler (2012) defines procurement optimization as the determination of basic long term goals of an organization and the determination of courses of actions and the allocation of resources necessary to carry out these goals. Procurement optimization thus helps an organization in utilization of its resources so as to give value to customers and in so doing achieve its objectives. According to Fred (2009), procurement optimization is the process and approach of specifying an organization's objectives, developing policies and plans to achieve and attain these objectives, and allocating resources so as to implement the policies and plans. In other words, procurement optimization can be seen as a combination of strategy formulation, implementation and evaluation. According to Johnson and Scholes (2010), the choice of a suitable procurement strategy to be pursued by an organization depends on the external environment in which the organization operates and its internal environment characterized by its strengths and weaknesses. The strategy must also be consistent with the firm's vision, mission and objectives. In procurement optimization, the firm must analyze the advantages, disadvantages, trade-offs, costs and benefits of each alternative strategy. The ultimate success of the identified strategy depends on its implementation. According to Pearce and Robinson (2009), procurement optimization provides long term direction for the firm and helps the firm cope with change and enables it to focus resources and efforts in the market.

\subsection{Statement of the Problem}

Procurement optimization is a very important component in the success of operations in any organization. The logic of this trend is that an organization increasingly focuses on those activities in the value chain where it has a distinctive advantage and outsources everything else (Oyuke \& Shale, 2014). Procurement optimization is a well-established and proven method for managing large-scale, medium to long term procurement activities. It has been adopted as standard practice by numerous public and private organizations in developed countries (Arrowsmith \& Trybus, 2010). County governments continue to experience major challenges in procurement performance. Kenyan central government spends about Kshs. 234 billion per year on procurement; however, the government loses close to $17 \%$ of the national budget due to 
inflated price quotations and other irregularities (Ngugi \& Mugo, 2012). In the year 2015, the county government of Kakamega lost Ksh. 200 million and in the year 2016, a total of Ksh. 93 million is said to have been embezzled from the infrastructure projects (Otieno, 2016). The inefficiency and ineptness of overall implementation of procurement practices in county governments contributes to loss of over Ksh.10 billion annually (PPOA, 2015).

According to Thomson and Jackson (2017) procurement expenditure could be minimized through proper implementation of procurement optimization. According to Arnott (2017) 70\% of an organization's sales revenues are spent on purchasing inputs hence if procurement costs can be reduced, this can improve returns on investment by increasing both profit margins and asset turnover rate. Same applies to county government projects where procurement consumes $60 \%$ of the projects cost according to Wanyama (2013). It is clear that despite the significant role of procurement function in the public sector, there is inadequate literature from previous empirical studies related to factors affecting efficiency of procurement function particularly among the county government in Kenya. A study by Ndiiri (2016) on performance of procurement in county governments in Kenya mainly focused on E-procurement implementation. Another study by Nzambu (2015) on determinants of procurement performance in county governments did not sufficiently address the drivers of procurement optimization in selected county governments in Kenya. While numerous researches have unraveled factors affecting procurement optimization (Korir, 2009; Kinoti, 2013) most of them have not exhaustively investigated procurement optimization within county governments. It is against this back drop that this study seeks to examine the determinants of procurement optimization in selected county governments in Kenya.

\subsection{Research objectives}

i. To assess the effect of vendor management on procurement optimization in selected county governments in Kenya.

ii. To establish the effect of risk management on procurement optimization in selected county governments in Kenya.

iii. To determine the effect of information technology adoption on procurement optimization in selected county governments in Kenya.

iv. To analyze the effect of value for money on procurement optimization in selected county governments in Kenya.

\subsection{LITERATURE REVIEW}

\subsection{Theoretical Review}

\subsubsection{Reinforcement Theory}

This theory is based on operant conditioning developed initially by a psychologist by the name of B.F. Skinner (1988). The theory argues that the behavior of people is largely determined by its consequences. Those actions that tend to have positive consequences tend to be repeated in future while those with negative consequences are unlikely to be repeated again (Otube, 2010). As such, decision makers in organizations should endeavor to ensure that consequences of good performance are pleasant while those of poor performance are unpleasant. With regard to vendor management, it should be made quite clear that meeting or surpassing the appraisal criteria would result in winning the confidence of the appraiser. This would ultimately result in the 
appraise benefiting by having contracts awarded to them which according to this theory, can be referred to as the 'pleasant consequence' (Brown, 2011). The basic idea underlying reinforcement theory is the concept of reinforcement itself. An event is said to be reinforcing if the event following some behavior makes the behavior more likely to occur again in future. According to Christensen (2010), positive reinforcement entails use of positive consequences that stimulates the desired behavior and strengthens the probability of repeat in such behavior in future. Suppliers can get positive reinforcement by being assured of continued business partnership should they continue meeting the client's expectations. They can also be issued with recommendation letters or certificates of exemplary performance to motivate them to continue performing well negative reinforcement this is also referred to as "avoidance learning". It involves use of unpleasant consequences to condition individuals from behaving in undesirable manner (Davis, 2015). By making unpleasant consequences contingent on undesirable performance, suppliers will systematically change their ways and endeavor to meet the requirements of their clients. By so doing, the resultant win-win situation will ensure that the performance of the procurement function is positively affected. In vendor management, consequences of not meeting the scoring criteria should be made known in the tender or request for quotation documents to serve as an alert against negative consequences (Lysons \& Gullingham, 2013).

Extinction involves withdrawal of all kinds of reinforcement to extinguish undesirable behavior. There are individuals who like the attention that is brought about by undesirable behavior. A practical example is one where a supplier deliberately delays delivery of items just to have the client make several follow-ups. The supplier may come up with all sorts of excuses for the delay, most of which are fictitious as he is only seeking attention (Christine, 2016). By ignoring such a supplier, the attention they are seeking is withheld and they will not repeat the same in future. Punishment works perfectly when an undesirable behavior needs to be reduced or eliminated. According to Martin (2014), to continue enjoying the good results, the suppliers are likely to do all they can to ensure they keep scoring well and maintain good performance in future. The poor performance they may record in some areas or instances is unlikely to be repeated in future events. A procuring entity that applies prudent supplier evaluation stand to greatly benefit from good or improved performance of its procurement function now and in the future. Good vendor management using the key parameters which are financial stability, quality aspects, reliability and past performance is a tool that can be used to put the reinforcement theory into practice in the area of strategic procurement management (Carter, 2010).

\subsubsection{Principal Agent Theory}

Agency theory was exposited by Alchian and Demsetz (1972) and further developed by Jensen and Meckling (1976). The theory defines the relationship between the principal that is the Contracting Authority. In this theory, the CA is the procuring entity that hires the agents to perform work. Principals delegate the running of projects to the private sector, who are the shareholders' agents (Clarke, 2014). According to Rungtusanatham (2009), two parties have an agency relationship when they cooperate and engage in an association wherein one party delegates decisions or work to another to act on its behalf. The important assumptions underlying agency theory are that potential goal conflicts exist between principals and agents each party acts in its own self-interest; information asymmetry frequently exists between principals and agents; agents are more risk averse than the principals; and efficiency is the effectiveness criterion 
(Xingxing \& Kaynak, 2012). The PAT highlights two problems arising from the information asymmetry: adverse selection and moral hazard (Laffont \& Martimort, 2012). This theory stipulates the underlying assumptions about the exercise of property rights and gives guidance in the writing of contracts that define organizations (Nguri, 2009). The theory particularly informs on relationships between the principal and the agent who act on behalf of the organization. According to this theory the principals must deal with two basic issues in selecting, choosing and controlling their agents: first, they have to select the best agents, whether employees or contractors, and create incentives for them to behave as principals' desire. Second, they have to check closely through monitoring the behavior of their agents to make sure that they are working and performing as agreed (Ayee, 2015). Problems such as Information asymmetry spring up when there is a goal conflict between the parties or when the process of verification of what the agent is doing becomes difficult or expensive for the principal.

\subsubsection{E-Technology Perspective Theory}

This theory was developed by M Wagner (1962) it mainly explains how information technology based procurement will increase efficiency in a firm. In this theory information technology based procurement enables customers and suppliers to increase networking channel through the internet in terms of production planning, demand management and inventory management, (Lee, 2013). Information technology based procurement facilitates frictionless procurement paradigm (Brousseau, 2010). The research by Min and Galle (2012) recognizes the extensive nature of information technology based procurement which refers to procurement as a business-tobusiness (B2B) purchasing practice that utilizes electronic procurement to identify potential sources of supply to purchase goods and services, interact with suppliers and transfer payment. The internet has been widely adopted by companies with the aim of improving organizational performances both in internal processes and in external processes (Barratt \& Rosdahl, 2012). Despite the fact that business-to-business (B2B) trade has enjoyed a longer existence online than business-to-consumer (B2C) the benefits of information technology based procurement in a B2B setting are significant (Min \& Galle, 2012). Previous studies have claimed that information technology based procurement has become the catalyst that allows companies to integrate their supply chains from end-to-end from supplier to the end user with shared performance, availability and pricing data that allows buyers and suppliers to work to optimum and mutually beneficial schedules and prices (Morris, 2010). Usually companies adopt information technology based procurement systems in order to manage the purchase products and services (Min \& Galle, 2012). In summary it has been noted that the influence of information technology based procurement adoption remains in a formative stage, falling short of the type of e-collaboration and e-sourcing suggested by (Morris, 2010). Common information technology based procurement tools are direct auctions and online catalogues where reverse auctions remain unpopular (Basheka \& Bisangabasaija, 2010).

\subsubsection{Public Value Theory}

Public value theory was formulated by Prof. Mark Moore (1995) to provide public sector managers with a greater understanding of the constraints and opportunities within which they work, and the challenge to create publically valuable outcomes. Benington and Moore (2010) argue that public value theory envisages a manager's purpose as going beyond implementation of policy and adherence to institutional norms. It includes seeking out opportunities to make 
significant improvements to the lives of the public. Moore (1995) also notes that public value theory articulates a more proactive and strategic role for public sector managers who seek to discover, define and produce public value, instead of just devising means for achieving mandated purposes. So, rather than procuring projects using traditional procurement methods, a public sector client might decide to pursue a project as long as they can account for cost and saving throughout the project lifetime (Amekudzi, 2008). According to Constable, Passmore and Coats (2008) unlike private enterprise, organizations providing public services are directly accountable to citizens and their democratic representatives. This theory was important in explaining VFM when applied to a county, which means that a county is supposed to bring larger value for the money that the public sector spends, compared to when services are provided 'in-house' (by public agencies) or when services are contracted out to a private company. The underlying logic is that using a county will make sense, in the opinion of many, only if it can deliver public sector services cheaper and better, meaning with smaller costs as opposed to other options, and with improved quality (and other enhanced output features) as opposed to other options. If value for money is not achieved, for example, when government costs of the project are higher than costs involved in the direct public service provision, a county should not be employed to achieve public procurement when the private sector pays a comparatively economic price for the highest possible specification capable of meeting the expected goals.

\subsection{Conceptual framework}

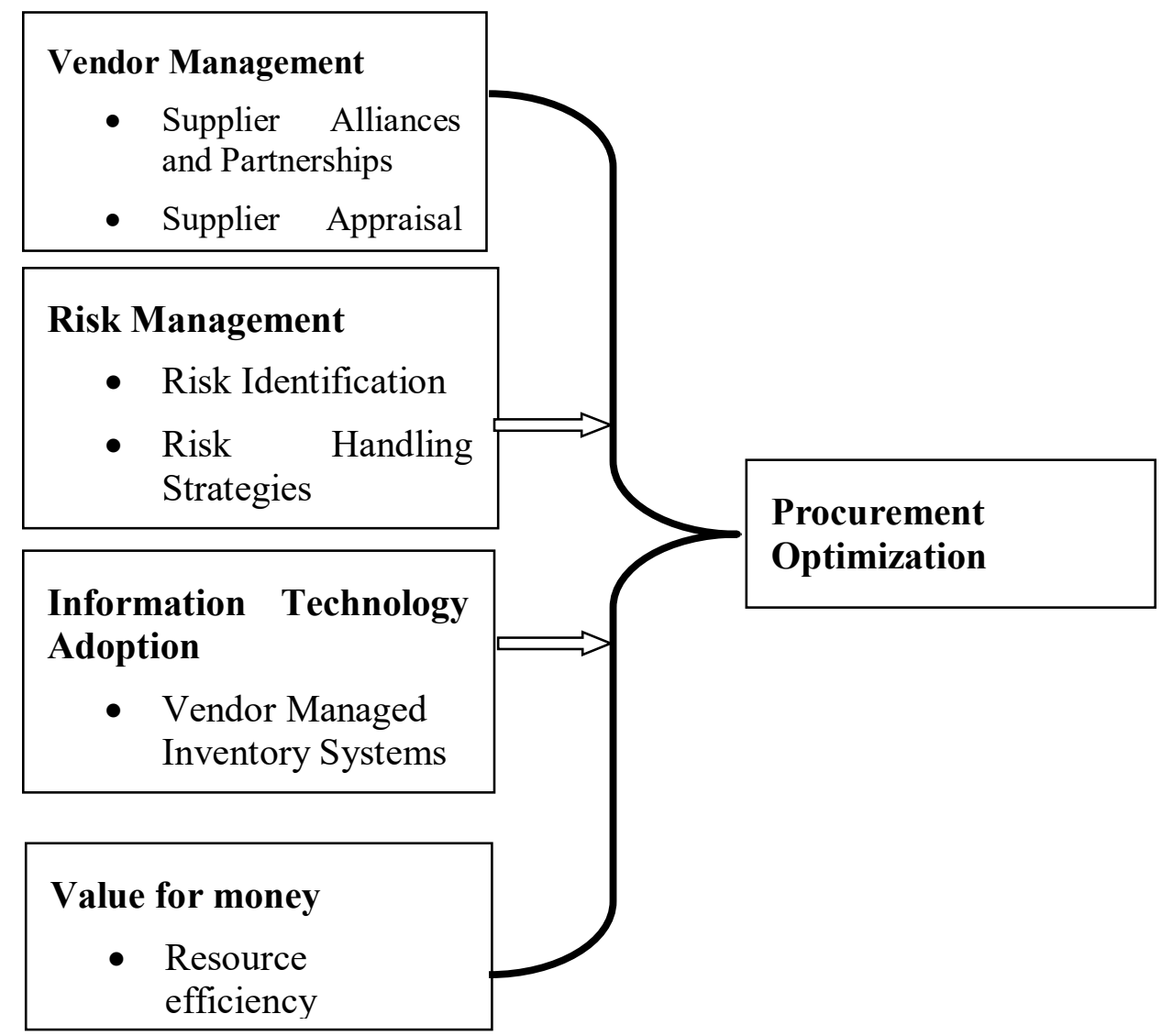




\section{Figure 1: Conceptual Framework}

\subsection{RESEARCH METHODOLOGY}

The study adopted a descriptive research design and targeted five county governments of Kenya (Nairobi, Machakos, Kiambu, Kajiando and Makueni). The unit of observation comprised of Chief Finance Officers in charge of Finance and Economic Planning, Heads of the Supply Chain Management Unit and Procurement staff at the departmental level in the selected Counties. A total of 136 respondents were involved in the study. The study used questionnaires in collecting data. Inferential and descriptive statistics was used to analyse data. Results of the analysis were presented by use of tables and figures. The study used the following regression model:

$Y=\beta_{0}+\beta_{1} X_{1}+\beta_{2} X_{2}+\beta_{3} X_{3}+\beta_{4} X_{4}+\varepsilon$

Where $\mathbf{Y}=$ Procurement Optimization, $\boldsymbol{\beta} \mathbf{0}=$ Constant Coefficient, $\mathbf{X}_{\mathbf{1}}=$ Vendor Management, $\mathbf{X}_{\mathbf{2}}=$ Risk Management, $\mathbf{X}_{\mathbf{3}}=$ Information Technology Adoption, $\mathbf{X}_{\mathbf{4}}=$ Value for money and $\boldsymbol{\varepsilon}=$ Random Error Term

\subsection{RESULTS}

The study administered 136 questionnaires where 98 questionnaires were filled and returned. This represented a response rate of $72.1 \%$. This response rate was within what Marshall and Rossman (2011) prescribed as a significant response rate for statistical analysis and established at a minimal value of $50 \%$.

\subsection{Descriptive statistics}

\section{Vendor Management and Procurement Optimization}

The study sought to assess the effect of vendor management on procurement optimization in county governments within Nairobi Metropolis. On challenges that their organisation experienced when it was implementing the existing vendor management system, they indicated clogging of the system by vendors with unqualified candidates to try to hit quotas, hard to communicate through a VMS and vendors not being competent. Therefore researcher asked the respondents to rate the vendor management system that their organisation uses currently. Their responses were presented in Table 4.1. From the findings, the respondents indicated that vendor management system that their organisation uses currently is effective as shown by $44.9 \%$. Others indicated somehow effective as shown by $27.6 \%$, very effective as shown by $20.4 \%$ and ineffective as shown by $7.1 \%$. This implies that the currently used vendor management system in most of county governments is effective. This conforms to Hartley (2012) who undertook a study on the effect of supplier management on performance in the Korean automotive industry and observed that while the price fluctuation might reduce purchase prices for the buyers in times of shortages, they may also negatively affect other aspects of supplier performance, as suppliers attempt to recoup profits by providing lower levels of service and product quality. 
International Journal of Supply Chain and Logistics

ISSN 2520-3983 (Online)

Vol. 3, Issue 2, pp 40-61, 2019

$\underline{\text { www.carijournals.org }}$

Table 4.1: Rating of the Currently Used Vendor Management System

\begin{tabular}{lll}
\hline Ratings & Frequency & Percent \\
\hline Ineffective & 7 & 7.1 \\
Somehow effective & 27 & 27.6 \\
Effective & 44 & 44.9 \\
Very effective & 20 & 20.4 \\
Total & $\mathbf{9 8}$ & $\mathbf{1 0 0 . 0}$ \\
\hline
\end{tabular}

The researcher further asked the respondents to indicate their level of agreement with the various statements on vendor management. Their responses were presented in Table 4.2.

From the study findings, the respondents agreed that supplier alliances and partnerships play a significant influence in lead time reduction as shown by a mean of 4.3469 , that Early supplier involvement plays a significant influence in increasing customer satisfaction as shown by a mean of 4.3469, that early supplier involvement plays a significant influence in cost reduction as indicated by a mean of 4.0102 and that supplier appraisal and development plays a significant influence in increasing customer satisfaction as shown by a mean of 3.8341 .

Table 4.2: Level of Agreement with Vendor Management Statements

\begin{tabular}{lcc}
\hline Statements & Mean & Std. Devi. \\
\hline $\begin{array}{l}\text { Supplier alliances and partnerships play a significant influence in cost } \\
\text { reduction }\end{array}$ & 3.9286 & .6300 \\
$\begin{array}{l}\text { Supplier appraisal and development plays a significant influence in cost } \\
\text { reduction }\end{array}$ & 2.4490 & .8194 \\
$\begin{array}{l}\text { Early supplier involvement plays a significant influence in cost reduction } \\
\text { Supplier alliances and partnerships play a significant influence in lead }\end{array}$ & 4.0102 & .8185 \\
time reduction & & .6750 \\
$\begin{array}{l}\text { Supplier appraisal and development plays a significant influence in lead } \\
\text { time reduction }\end{array}$ & 3.1531 & .8586 \\
$\begin{array}{l}\text { Early supplier involvement plays a significant influence in lead time } \\
\text { reduction }\end{array}$ & 3.7653 & .8828 \\
$\begin{array}{l}\text { Supplier alliances and partnerships play a significant influence in } \\
\text { increasing customer satisfaction }\end{array}$ & 2.6218 & .7191 \\
$\begin{array}{l}\text { Supplier appraisal and development plays a significant influence in } \\
\text { increasing customer satisfaction }\end{array}$ & 3.8341 & .9185 \\
$\begin{array}{l}\text { Early supplier involvement plays a significant influence in increasing } \\
\text { customer satisfaction }\end{array}$ & 4.3469 & .7751 \\
\hline
\end{tabular}

The respondents also agreed that supplier alliances and partnerships play a significant influence in cost reduction as shown by a mean of 3.9286 and that early supplier involvement plays a significant influence in lead time reduction as expressed by a mean of 3.7653. This concurs with Alex (2013) who argues that the most successful relationships are those in which customers and suppliers develop trust and understanding of their respective requirements and interests, accompanied by a concern to learn and demonstrate mutual assistance. Moreover, the respondents were neutral that their supplier appraisal and development plays a significant influence in lead time reduction as illustrated by a mean of 3.1531, were neutral that Supplier 
alliances and partnerships play a significant influence in increasing customer satisfaction as shown by a mean of 2.6218 and disagreed that supplier appraisal and development plays a significant influence in cost reduction as represented by a mean of 2.4490 . This conforms to Ford et al., (2013) who cite such a business-to-business approach, marketing relationships with the management of a series of relationships between buyers and suppliers in the context of a wider network of interconnected purchases, suppliers and competing organizations.

\section{Risk Management and Procurement Optimization}

The study also sought to establish the effect of risk management on procurement optimization in county governments within Nairobi Metropolis. On challenges that the respondents organization experienced when it was adopting the risk management practices that are in place, the respondents indicated lack of trained professionals. The researcher also required the respondents to rate the risk management practices that their organization has in place. Their replies were as shown in Table 3. From the findings, the respondents indicated that risk management practices that their organization has in place are effective as shown by $38.8 \%$, somehow effective as shown by $25.5 \%$, very effective as shown by $21.4 \%$ and ineffective as shown by $14.3 \%$. This shows that risk management practices that most of county governments have in place are effective. This is in line with Yougjian, Shouquig and Albert (2011) who conducted a study on equitable risk allocation of public projects in China with the purpose to elaborate on the preferred risk allocation for public projects and found a great degree of conformity between the preferred and actual risk allocation to be considered for equitable risk allocation in public projects.

\section{Table 4.3: Rating of Risk Management Practices}

\begin{tabular}{lll}
\hline Ratings & Frequency & Percent \\
\hline Ineffective & 14 & 14.3 \\
Somehow effective & 25 & 25.5 \\
Effective & 38 & 38.8 \\
Very effective & 21 & 21.4 \\
Total & $\mathbf{9 8}$ & $\mathbf{1 0 0 . 0}$ \\
\hline
\end{tabular}

The researcher also required the respondents indicate their level of agreement with the various statements on risk management using a Likert scale of 1-5. Their responses were as shown in Table 4.4

From the findings, the respondents were in agreement on the facts that risk handling strategies play a significant influence in cost reduction as expressed by a mean score of 4.3469 , that risk handling strategies play a significant influence in lead time reduction as shown by a mean of 4.1939 and that risk monitoring and review plays a significant influence in cost reduction as indicated by a mean of 4.0714. The respondents also agreed that risk identification plays a significant influence in increasing customer satisfaction as shown by a mean of 4.0967 and that risk handling strategies play a significant influence in increasing customer satisfaction as shown by a mean of 3.7141. This correlates with Laura, Stephen and Marco (2014) who investigated the criteria for risk allocation in energy from waste disposal in public projects through a comparative analysis of three case studies in Italy and the UK and highlighted the deficiencies of the criterion adopted for allocation of risk in public projects as allocating risk to the party best able to manage the risk. 
International Journal of Supply Chain and Logistics

ISSN 2520-3983 (Online)

Vol. 3, Issue 2, pp 40-61, 2019

www.carijournals.org

Table 4.4: Level of Agreement with Risk management Statements

\begin{tabular}{lcc}
\hline Statements & Mean & Std. Dev. \\
\hline Risk identification plays a significant influence in cost reduction & 2.7755 & .6815 \\
Risk handling strategies play a significant influence in cost reduction & 4.3469 & .6109 \\
Risk monitoring and review plays a significant influence in cost & 4.0714 & .6923 \\
reduction & & \\
$\begin{array}{l}\text { Risk identification plays a significant influence in lead time reduction } \\
\text { Risk handling strategies play a significant influence in lead time }\end{array}$ & 3.1939 & .9702 \\
reduction & & .6526 \\
$\begin{array}{l}\text { Risk monitoring and review plays a significant influence in lead time } \\
\text { reduction }\end{array}$ & & .7 .5918 \\
$\begin{array}{l}\text { Risk identification plays a significant influence in increasing } \\
\text { customer satisfaction }\end{array}$ & & \\
$\begin{array}{l}\text { Risk handling strategies play a significant influence in increasing } \\
\text { customer satisfaction }\end{array}$ & & .6112 \\
$\begin{array}{l}\text { Risk monitoring and review plays a significant influence in } \\
\text { increasing customer satisfaction }\end{array}$ & & .6937 \\
\hline
\end{tabular}

Additionally, the respondents were also in agreement with the fact that risk monitoring and review plays a significant influence in lead time reduction as expressed by a mean of 3.5918. They were however neutral on the fact that risk identification plays a significant influence in lead time reduction as illustrated by a mean of 3.1939 and that risk monitoring and review plays a significant influence in increasing customer satisfaction as shown by a mean of 3.0939 but disagreed on the fact that Risk identification plays a significant influence in cost reduction as indicated by a mean of 2.7755. This corresponds with Albert et al., (2011) who conducted a study on risk assessment and allocation with the aim to identify and assess the principle of risk for the delivery of public projects in China and address their proper risk allocation between public and private sector. The finding indicated that there should be a better understanding on how risk should be assessed and allocated for the public projects by both the private and public parties. Optimal risk allocation seeks to minimize the risks to the project by allocating particular risks to the party in the best position to control them.

\section{Information Technology Adoption and Procurement Optimization}

The study sought to determine the effect of information technology adoption on procurement optimization in selected county governments in Kenya. The researcher also requested the respondents to rate the information technology system in their organization. Their responses were as shown in Table 5. The respondents indicated that information technology adoption is effective as illustrated by $38.8 \%$, somehow effective as illustrated by $25.5 \%$, very effective as illustrated by $21.4 \%$ and ineffective as shown by $14.3 \%$. This indicates that information technology adoption in most of County governments is effective. This is in line with Shalle, Guyo and Emuhaya (2014) who argues that limited or non-existent access to timely information on national and export markets, in particular regarding issues such as supply volumes and quantities, led to shortages of supplies because the players I am never aware of the amount of orders the customer has made and how much should be requested from suppliers. To coordinate 
demand demands, transport organizations and inventory management should use the advantage of strategic supply chain tools, such as information technology, to reduce and simplify orders.

Table 4.5: Rating of Information Technology Adoption

\begin{tabular}{lll}
\hline Ratings & Frequency & Percent \\
\hline Ineffective & 14 & 14.3 \\
Somehow effective & 25 & 25.5 \\
Effective & 38 & 38.8 \\
Very effective & 21 & 21.4 \\
Total & $\mathbf{9 8}$ & $\mathbf{1 0 0 . 0}$ \\
\hline
\end{tabular}

The researcher also requested the respondents to give their response on their level of agreement with various statements information technology adoption. Their responses were as shown in Table 4.6.

As per the outcomes, the respondents were in general consensus that vendor managed inventory systems plays a significant influence in cost reduction as expressed by a mean score of 4.3469, that material resource planning plays a significant influence in lead time reduction as indicated by a mean of 4.1224 , that bar coding of items plays a significant influence in cost reduction as expressed by a mean of 4.0102 and that material resource planning plays a significant influence in cost reduction as illustrated by a mean of 3.7653. The respondents further agreed that vendor managed inventory systems plays a significant influence in increasing customer satisfaction as shown by a mean of 3.9781 and that bar coding of items plays a significant influence in increasing customer satisfaction as shown by a mean of 3.6613 .

Table 4.6: Statements on Information Technology Adoption

\begin{tabular}{lcc}
\hline Statements & Mean & Std. Dev. \\
\hline $\begin{array}{l}\text { Vendor managed inventory systems plays a significant influence in cost } \\
\text { reduction }\end{array}$ & 4.3469 & .7878 \\
$\begin{array}{l}\text { Bar coding of items plays a significant influence in cost reduction } \\
\text { Material resource planning plays a significant influence in cost reduction }\end{array}$ & 4.0102 & .8185 \\
$\begin{array}{l}\text { Vendor managed inventory systems plays a significant influence in lead } \\
\text { time reduction }\end{array}$ & 2.6327 & .8348 \\
$\begin{array}{l}\text { Bar coding of items plays a significant influence in lead time reduction } \\
\text { Material resource planning plays a significant influence in lead time }\end{array}$ & 2.6735 & .47224 \\
$\begin{array}{l}\text { Veduction } \\
\text { Vendor managed inventory systems plays a significant influence in }\end{array}$ & 3.9781 & .8527 \\
$\begin{array}{l}\text { increasing customer satisfaction } \\
\text { Bar coding of items plays a significant influence in increasing } \\
\text { customer satisfaction }\end{array}$ & 3.6613 & .8482 \\
$\begin{array}{l}\text { Material resource planning plays a significant influence in increasing } \\
\text { customer satisfaction }\end{array}$ & 2.6117 & .8777 \\
\hline
\end{tabular}

These findings agree with Milne (2016) who argues that the technology helps to synchronize and balance the two opposing business goals to get the best low-cost customer service. Most companies want to have a very high level of customer service, but want to do it at the lowest possible cost. Supply chain technology can help companies evaluate rewards to meet their 
customers' needs, but in a way that allows them to make a profit. Nevertheless, the respondents were neutral that bar coding of items plays a significant influence in lead time reduction as shown by a mean of 2.6735 , that vendor managed inventory systems plays a significant influence in lead time reduction as indicated by an average of 2.6327 and that Material resource planning plays a significant influence in increasing customer satisfaction as shown by a mean of 2.6117. These concur with Kima and Shunk (2014) who argues that the acquisition of IT, but the objective is invariably two-fold: to allow the wide variety of purchase transactions on which each company depends and to arm decision-makers at all levels with meaningful and practicable information in a predictable and easily accessible way.

\section{Value for money and Procurement Optimization}

The study further sought to analyze the effect of value for money on procurement optimization in selected county governments in Kenya. The researcher further asked the respondents to rate the value for money system in their organization. Their responses were as shown in Table 7. As illustrated by the study outcomes, the respondents revealed that value for money system is effective as shown by $46.9 \%$, somehow effective as shown by $40.8 \%$ and ineffective as shown by $12.2 \%$. This clearly reveals that value for money system in most of county governments is effective. This concurs with Callender and Johnston (2002) who opined that VFM has been closely connected to the perception of lowest costs, superior quality, greater time performance, products and services that meet user's satisfaction and satisfactory profit to investors. VFM is therefore achieved in public procurement when the purchaser pays a comparatively economic price for the highest possible specification capable of meeting the expected goals.

Table 4.7: Rating of Value for Money System

\begin{tabular}{lll}
\hline Ratings & Frequency & Percent \\
\hline Ineffective & 12 & 12.2 \\
Somehow effective & 40 & 40.8 \\
Effective & 46 & 46.9 \\
Total & $\mathbf{9 8}$ & $\mathbf{1 0 0 . 0}$ \\
\hline
\end{tabular}

The researcher further asked the respondents to indicate their level of agreement with the various statements on value for money. Their responses were as shown in Table 4.8.

The respondents agreed that cost effectiveness in procurement optimization plays a significant influence in cost reduction (Mean=4.3469), that fair competition in procurement optimization plays a significant influence in lead time reduction (Mean=4.3469) and that resource efficiency in procurement optimization plays a significant influence in lead time reduction (Mean=4.0102).

Further the respondents agreed that fair competition in procurement optimization plays a significant influence in increasing customer satisfaction (Mean=4.0318, that resource efficiency in procurement optimization plays a significant influence in increasing customer satisfaction (Mean=3.9112) and that cost effectiveness in procurement optimization plays a significant influence in increasing customer satisfaction (Mean=3.7153). This concurs with Kušljic' and Marenjak (2013) who stated that "a PFI project can be described as successful if it delivers value for money in the form of cost effective, reliable and timely services at agreed prices and to agreed quality, as defined in the contract. 
Table 4.8: Statements on Value For Money

\begin{tabular}{|c|c|c|}
\hline Statements & Mean & Std. Dev. \\
\hline $\begin{array}{l}\text { Resource efficiency in procurement optimization plays a significant } \\
\text { influence in cost reduction }\end{array}$ & 2.8878 & .77170 \\
\hline $\begin{array}{l}\text { Fair competition in procurement optimization plays a significant influence } \\
\text { in cost reduction }\end{array}$ & 3.6224 & .97933 \\
\hline $\begin{array}{l}\text { Cost effectiveness in procurement optimization plays a significant influence } \\
\text { in cost reduction }\end{array}$ & 4.3469 & .78782 \\
\hline $\begin{array}{l}\text { Resource efficiency in procurement optimization plays a significant } \\
\text { influence in lead time reduction }\end{array}$ & 4.0102 & .81853 \\
\hline $\begin{array}{l}\text { Fair competition in procurement optimization plays a significant influence } \\
\text { in lead time reduction }\end{array}$ & 4.3469 & .67506 \\
\hline $\begin{array}{l}\text { Cost effectiveness in procurement optimization plays a significant influence } \\
\text { in lead time reduction }\end{array}$ & 3.8163 & .66343 \\
\hline $\begin{array}{l}\text { Resource efficiency in procurement optimization plays a significant } \\
\text { influence in increasing customer satisfaction }\end{array}$ & 2.4388 & .70442 \\
\hline $\begin{array}{l}\text { Resource efficiency in procurement optimization plays a significant } \\
\text { influence in increasing customer satisfaction }\end{array}$ & 3.9112 & $.88^{`} 3$ \\
\hline $\begin{array}{l}\text { Fair competition in procurement optimization plays a significant } \\
\text { influence in increasing customer satisfaction }\end{array}$ & 4.0318 & .7106 \\
\hline Cost effectiveness in procurement optimization plays a significant & 3.7153 & .8643 \\
\hline
\end{tabular}

There are different approaches for conducting value for money assessment. Moreover, the respondents agreed that cost effectiveness in procurement optimization plays a significant influence in lead time reduction (Mean=3.8163) and that fair competition in procurement optimization plays a significant influence in cost reduction (Mean=3.6224). However, the respondents were neutral that resource efficiency in procurement optimization plays a significant influence in cost reduction (Mean=2.8878) and disagreed that resource efficiency in procurement optimization plays a significant influence in increasing customer satisfaction (Mean=2.4388). This is in line with Moralos and Amekudzi (2008) who described VFM as the best available outcome for the cost savings, benefits and appropriate risk allocation throughout a project lifetime which focusing on quality and competency to meet the public requirements.

\section{Procurement optimization in selected county governments in Kenya}

The respondents were asked to indicate the margin of reduction in cost over the last five years. Their responses were as shown in Table 4.9.

From the findings, majority of the respondents indicated a cost reduction margin of 3 to 4 million in 2013 as shown by $38.8 \%, 2$ to 3 million in 2014 as shown by $34.7 \%$ and 3 to 4 million in 2015 as shown by $44.9 \%$. Further the respondents indicated a cost reduction margin of 3 to 4 million in 2016 as shown by $49 \%$ and 3 to 4 million in 2017 as shown by $46.9 \%$. Averagely, the cost reduction margin for most of the counties selected in this study was 3 to 4 million. This implies various determinants of procurement optimization in county governments have led to cost reduction. This is in line with Ellram and Liu (2009) who argues that in order for the 
International Journal of Supply Chain and Logistics

ISSN 2520-3983 (Online)

Vol. 3, Issue 2, pp 40-61, 2019

www.carijournals.org

organizations to achieve procurement optimization competence of those to drive the change is a must. This is because it enhances organizational capability and effectiveness.

Table 4.9: Margin of Reduction in Cost (in Millions)

\begin{tabular}{lllllllllll}
\hline & $\mathbf{2 0 1 3}$ & & $\mathbf{2 0 1 4}$ & & $\mathbf{2 0 1 5}$ & & $\mathbf{2 0 1 6}$ & & $\mathbf{2 0 1 7}$ & \\
\hline & $\mathbf{F}$ & $\mathbf{P}$ & $\mathbf{F}$ & $\mathbf{P}$ & $\mathbf{F}$ & $\mathbf{P}$ & $\mathbf{F}$ & $\mathbf{P}$ & $\mathbf{F}$ & $\mathbf{P}$ \\
\hline $0-1$ & 9 & 9.2 & 6 & 6.1 & 1 & 1.0 & 16 & 16.3 & 3 & 3.1 \\
$1-2$ & 11 & 11.2 & 8 & 8.2 & 13 & 13.3 & 8 & 8.2 & 19 & 19.4 \\
$2-3$ & 24 & 24.5 & 34 & 34.7 & 22 & 22.4 & 18 & 18.4 & 22 & 22.4 \\
$3-4$ & 38 & 38.8 & 28 & 28.6 & 44 & 44.9 & 48 & 49.0 & 46 & 46.9 \\
More than 4 & 16 & 16.3 & 22 & 22.4 & 18 & 18.4 & 8 & 8.2 & 8 & 8.2 \\
Total & $\mathbf{9 8}$ & $\mathbf{1 0 0 . 0}$ & $\mathbf{9 8}$ & $\mathbf{1 0 0 . 0}$ & $\mathbf{9 8}$ & $\mathbf{1 0 0 . 0}$ & $\mathbf{9 8}$ & $\mathbf{1 0 0 . 0}$ & $\mathbf{9 8}$ & $\mathbf{1 0 0 . 0}$ \\
\hline
\end{tabular}

Key: F-Frequency, P-Percent

Further the respondents were asked to indicate margin of delivery time reduction in delivery of supplies over the last five years. Their replies were as shown in Table 10.

Table 4.10: lead Time Reduction (in Weeks)

\begin{tabular}{lllllllllll}
\hline & $\mathbf{2 0 1 3}$ & & $\mathbf{2 0 1 4}$ & & $\mathbf{2 0 1 5}$ & & $\mathbf{2 0 1 6}$ & \multicolumn{2}{c}{$\mathbf{2 0 1 7}$} \\
\hline & $\mathbf{F}$ & $\mathbf{P}$ & $\mathbf{F}$ & $\mathbf{P}$ & $\mathbf{F}$ & $\mathbf{P}$ & $\mathbf{F}$ & $\mathbf{P}$ & $\mathbf{F}$ & $\mathbf{P}$ \\
\hline $0-1$ & 17 & 17.3 & 63 & 64.3 & 1 & 1.0 & 13 & 13.3 & 9 & 9.2 \\
$1-2$ & 2 & 2.0 & 3 & 3.1 & 66 & 67.3 & 11 & 11.2 & 22 & 22.4 \\
$2-3$ & 63 & 64.3 & 13 & 13.3 & 12 & 12.2 & 39 & 39.8 & 12 & 12.2 \\
$3-4$ & 12 & 12.2 & 12 & 12.2 & 12 & 12.2 & 23 & 23.5 & 44 & 44.9 \\
More than 4 & 4 & 4.1 & 7 & 7.1 & 7 & 7.1 & 12 & 12.2 & 11 & 11.2 \\
Total & $\mathbf{9 8}$ & $\mathbf{1 0 0 . 0}$ & $\mathbf{9 8}$ & $\mathbf{1 0 0 . 0}$ & $\mathbf{9 8}$ & $\mathbf{1 0 0 . 0}$ & $\mathbf{9 8}$ & $\mathbf{1 0 0 . 0}$ & $\mathbf{9 8}$ & $\mathbf{1 0 0 . 0}$ \\
\hline
\end{tabular}

Key: F-Frequency, P-Percent

From the findings, most of the respondents indicated a margin of lead time reduction of 2 to 3 weeks in 2013 as shown by $64.3 \%, 0$ to 1 week in 2014 as shown by $64.3 \%$ and a margin of lead time reduction of 1 to 2 weeks in 2015 as shown by $67.3 \%$. Moreover, the respondents indicated a margin of lead time reduction of 2 to 3 weeks in 2016 as shown by $39.8 \%$ and 3 to 4 weeks in 2017 as shown by $44.9 \%$. This is an indication that various determinants of procurement optimization in county governments have led to lead time reduction. This is in line with Ellram 
and Liu (2009) who argues that in order for the organizations to achieve procurement optimization competence of those to drive the change is a must. This is because it enhances organizational capability and effectiveness. In a nutshell, changes would happen where there is good and capable leadership and management that will drive change in systems, culture and organization.

The researcher further asked the respondents to indicate their level of agreement with the various statements on service delivery. Their responses were as shown in Table 11.

Table 4.11: Statements on Service Delivery

\begin{tabular}{lcc}
\hline Statement & Mean & Std. Dev. \\
\hline $\begin{array}{l}\text { Efficiency in procurement optimization plays a significant role in } \\
\text { citizen satisfaction }\end{array}$ & 4.1531 & .67887 \\
$\begin{array}{l}\text { Procurement optimization has improved accessibility to sewer services } \\
\text { to citizens }\end{array}$ & 4.1020 & .50747 \\
$\begin{array}{l}\text { Procurement optimization has greatly improved provision of health } \\
\text { services to citizens }\end{array}$ & 3.4898 & .66185 \\
$\begin{array}{l}\text { Procurement optimization has resulted to access to better roads by } \\
\text { citizens }\end{array}$ & 3.6122 & .63624 \\
Procurement optimization has a great impact on the standards of living & 4.4286 & .78648 \\
\hline
\end{tabular}

From the study outcomes, the respondents agreed ion the facts that procurement optimization has a great impact on the standards of living as shown by a mean of 4.4286 , that efficiency in procurement optimization plays a significant role in citizen satisfaction as indicated by a mean of 4.1531, that procurement optimization has improved accessibility to sewer services to citizens as shown by a mean of 4.1020 and that procurement optimization has resulted to access to better roads by citizens as illustrated by a mean of 3.6122. Further, the respondents were neutral that procurement optimization has greatly improved provision of health services to citizens as shown by a mean of 3.4898. These findings correspond to Chandler (2012) who argues that procurement optimization is a unifying theme that gives coherence and direction to the actions and decisions of an organization. It guides an organization to superior performance by helping establish competitive advantage. It acts as a vehicle for communication and coordination within the organization. The goal of strategic management therefore is to build and maintain sustainable competitive advantage and create stakeholders' wealth. Procurement optimization process includes formulation, implementation, evaluation and control.

\subsection{Inferential Statistics}

\subsubsection{Multiple Regression Analysis}

Using multiple regression analysis was used to test the relationship between the variables where it shows how the dependent variable is influenced by the independent variables. The results shows that the independent variables were statistically significant predicting the dependent variable since $\mathrm{R}$ squared was 0.719 implying that vendor management, risk management, information technology adoption and value for money explains $71.9 \%$ variation in Procurement optimization in selected county governments in Kenya.

Table 4.12: Model Summary 
International Journal of Supply Chain and Logistics

ISSN 2520-3983 (Online)

Vol. 3, Issue 2, pp 40-61, 2019

www.carijournals.org

\begin{tabular}{lllll} 
Model & R & R Square & Adjusted R Square & Std. Error of the Estimate \\
\hline 1 & 0.848 & 0.719 & 0.707 & 0.707
\end{tabular}

The probability value of 0.000 in the ANOVA results indicates that the regression relationship was significant in determining how vendor management, risk management, information technology adoption and value for money influence procurement optimization in selected county governments in Kenya. The F calculated at 5 percent level of significance was 59.613. Since F calculated is greater than the F critical (Value $=2.2899$ ), the overall model was significant.

Table 4.131: ANOVA Results

\begin{tabular}{lllllll}
\hline Model & & Sum of Squares & Df & Mean Square & F & Sig. \\
\hline 1 & Regression & 123.121 & 4 & 30.780 & 59.613 & .000 \\
& Residual & 48.019 & 93 & 0.516 & & \\
& Total & $\mathbf{1 7 1 . 1 4}$ & $\mathbf{9 7}$ & & & \\
\hline
\end{tabular}

The findings on the model of coefficient presented show that taking all other independent variables at zero, a unit increase in the vendor management would lead to a 0.716 increase in the score of procurement optimization in selected county governments in Kenya. This variable was significant since calculated t statistic (2.419) is greater than table value (1.660) at 5\% level of significance. This conforms to Hartley (2012) who undertook a study on the effect of supplier management on performance in the Korean automotive industry and observed that while the price fluctuation might reduce purchase prices for the buyers in times of shortages, they may also negatively affect other aspects of supplier performance, as suppliers attempt to recoup profits by providing lower levels of service and product quality. Further it was found that a unit increase in the score of risk management would lead to a 0.606 increase in the score of procurement optimization in selected county governments in Kenya. This variable was significant since calculated t statistic (2.913) is greater than table value (1.660) at 5\% level of significance. This is in line with Yougjian, Shouquig and Albert (2011) who conducted a study on equitable risk allocation of public projects in China with the purpose to elaborate on the preferred risk allocation for public projects and found a great degree of conformity between the preferred and actual risk allocation to be considered for equitable risk allocation in public projects. Further, the findings show that a unit increases in the scores of information technology adoption would lead to a 0.803 increase in the scores of procurement optimization in selected county governments in Kenya. This variable was significant since calculated t statistic (6.863) is greater than table value (1.660) at 5\% level of significance. These findings agree with Milne (2016) who argues that the technology helps to synchronize and balance the two opposing business goals to get the best lowcost customer service. Most companies want to have a very high level of customer service, but want to do it at the lowest possible cost. Supply chain technology can help companies evaluate rewards to meet their customers' needs, but in a way that allows them to make a profit. The study also found that a unit increases in the scores of value for money would lead to a 0.714 increase in the scores of procurement optimization in selected county governments in Kenya. This variable was significant since calculated t statistic (2.288) is greater than table value (1.660) at 5\% level of significance. This concurs with Callender and Johnston (2002) who opined that VFM has been closely connected to the perception of lowest costs, superior quality, greater time performance, products and services that meet user's satisfaction and satisfactory profit to investors. VFM is 
therefore achieved in public procurement when the purchaser pays a comparatively economic price for the highest possible specification capable of meeting the expected goals.

The established model for the study was:

Procurement optimization $=0.988+0.716($ Vendor management $)+0.606($ Risk management $)$ +0.803 (Information technology adoption) + 0.714(Value for money).

Table 4.14: Regression Coefficients

\begin{tabular}{|c|c|c|c|c|c|}
\hline \multirow[t]{2}{*}{ Model } & \multicolumn{2}{|c|}{$\begin{array}{l}\text { Unstandardized } \\
\text { Coefficients }\end{array}$} & \multirow{2}{*}{$\begin{array}{l}\text { Standardized } \\
\text { Coefficients } \\
\text { Beta }\end{array}$} & \multirow[t]{2}{*}{$\mathbf{t}$} & \multirow[t]{2}{*}{ Sig. } \\
\hline & $\mathbf{B}$ & $\begin{array}{l}\text { Std. } \\
\text { Error }\end{array}$ & & & \\
\hline (Constant) & 0.988 & 0.182 & & 5.429 & .000 \\
\hline Vendor management & 0.716 & 0.296 & 0.623 & 2.419 & .020 \\
\hline Risk management & 0.606 & 0.208 & 0.527 & 2.913 & .005 \\
\hline Information technology adoption & 0.803 & 0.117 & 0.699 & 6.863 & .000 \\
\hline Value for money & 0.714 & 0.312 & 0.621 & 2.288 & .027 \\
\hline
\end{tabular}

The regression equation above has established that taking (vendor management, risk management, information technology adoption and value for money), procurement optimization in selected county governments in Kenya will be 0.988 . Overall, information technology adoption had the greatest effect on procurement optimization in selected county governments in Kenya followed by vendor management then value for money while risk management had the least effect on the procurement optimization in selected county governments in Kenya in Kenya. All variables were significant as their calculated t statistics were greater than table value (1.660) at $5 \%$ level of significance.

\subsection{CONCLUSIONS AND RECOMMENDATIONS}

\subsection{Conclusion}

The study concluded that vendor management affects procurement optimization in selected county governments in Kenya positively and significantly. This was attributed to the fact that most of counties have effective vendor management system. The study also established that supplier alliances and partnerships play a significant influence in lead time and cost reduction and that early supplier involvement plays a significant influence in increasing customer satisfaction and influencing cost reduction. On the same note it was established that supplier appraisal and development plays a significant influence in increasing customer satisfaction and in lead time reduction. Further the study concluded that risk management positively and significantly affects the procurement optimization in selected county governments in Kenya. The counties were established to have in place effective risk management practices. This indicated that in most counties risk handling strategies play a significant influence in cost reduction, in lead time reduction and in increasing customer satisfaction. The risk monitoring and review were established to play a significant influence in cost reduction, in lead time reduction and in increasing customer satisfaction. Further, the risk identification plays a significant influence in increasing customer satisfaction in lead time reduction and in cost reduction. 
Moreover, the study concluded that information technology adoption significantly affects the procurement optimization in selected county governments in Kenya. The information technology adoption in most of County governments were established to be effective. Vendor managed inventory systems, material resource planning and bar coding of items were deduced to plays a significant influence in cost reduction, in lead time reduction and in increasing customer satisfaction. Additionally, the study concluded that value for money positively and significantly affects the procurement optimization in selected county governments in Kenya. It was clear that value for money system in most of county governments was effective. This was attributed to the fact that effectiveness in procurement optimization, economy in procurement optimization and efficiency in procurement optimization plays a significant influence in cost reduction, in lead time reduction and in increasing customer satisfaction.

\subsection{Recommendations}

The study recommended for the county governments to ensure that there is use inventory management system and automated recording, cycle counting Inventory control; use of E.O.G. There is need to have replenishment level/ reorder level management in the firm and ensure that there is a continuous periodic review. This would enhance procurement efficiency in the county governments in Kenya. The study recommended for adequate financial capacity to enhance procurement efficiency in the county Governments. There is a need to have adequate provision of competitive wages and benefits for procurement personnel. There was need for adequate funding for procurement processes and all activities should be captured in the planned budget. The fund disbursement for procurement processes should be timely. There was need to have a timely processing of payment to suppliers and bidders should have adequate capital to undertake contracts they are awarded. The study thus recommends that the county governments should be sensitive of the ever changing business environment that dictates the competitive environment they operate in. As such, staying ahead of the competition through adoption of ICT would ensure that the organizations survive in the competitive environment. Embracing of Information Communication Technology (ICT) ensures that the supply chain balances its need to satisfy customer needs and also to manage costs so as to attain profits. The study recommends all the relevant stakeholders with regards to procurement to be involved in procurement of necessary materials, goods and services. More so the procurement department should asses the experience and capacity of the prospective suppliers and service providers so as to ensure timely services delivery which is according to the specifications. It further recommend a capacity building for procurement staff which will equip them with the necessary skills required to handle dynamic changes of procurement systems at the county government. Furthermore procurement staff should be adequately equipped with tools and equipment necessary to execute their duties. In addition, the study recommend timely procurement budgeting which should be presented for approval on time. Adequate finances to be allocated to procurement activities which should be presented to the head of procurement at the right time. Management should come up with policies to curb mismanagement of at the county level which should include Strong financial management mechanisms in order to avoid wastage during procurement processes and activities

\subsection{ACKNOWLEDGEMENT}

I wish to thank God for giving me a gift of life to write this project, I wish to express my gratitude to my supervisor Dr. Allan Kihara for his professional guidance and motivation that 
International Journal of Supply Chain and Logistics

ISSN 2520-3983 (Online)

Vol. 3, Issue 2, pp 40-61, 2019

www.carijournals.org

enabled me compile this project, I also extend gratitude to my course mates whose presence

offered me motivation and need to learn.

\section{REFERENCES}

Alchian, A \& Demsetz, H. (2011). Production, information cost and economic organisation. American Economic Review.

Brown, T. L, Potoski, M \& Van Slyke, D. M. (2016). Managing public service contracts. Alining values, Institutions and markets. Public Administration Review.

Carter, C. R. (2010). Ethical Issues in International Buyer-supplier relationships: a dyadic examination. International Journal of Operations Management.

Chan, A.P.C., Yeung, J.F.Y., Yu. C.C.P., Wang, S.Q. \& Ke,Y. (2011). Empirical study of risk assessment and allocation of public-partnership projects in China. ASCE Journal of Management in Engineering, 9(2), 136-148.

Choi, J. (2010). A study of the role public procurement - can public procurement make society better? The International Public Procurement Conference, Seoul, South Korea

Christine, A. (2016). Public procurement as a lever of government reform: International Journal on Scientific Research

Donald, C. (2009). Synthesizing Research; A guide for Literature Reviews (3rd edn) Sage: Thousand Oaks

Government of Kenya. (2018) Kenya Gazzette Supplement. Government Printer. Nairobi.

Jackson, P. (2014). Value for money and international development. Journal of OECD Development .

John, G. \& Johnson, P. (2012). Research methods for Managers, 4th Edition. Sage Publications: London.

Lysons, K., \& Gullingham, M. (2013). Purchasing and Supply Chain Management, (6th Ed). London: Pearsons Hall.

Mahmood, S. A. (2010). Public Procurement and Corruption in Bangladesh. Confronting the Challenges and Opportunities. Journal of Public Administration and Policy Research, 2(6), 103-111.

Ndiiri. F. K (2016) E-procurement Implementation and Performance of County Governments in Kenya MBA research project University of Nairobi

Ngugi, J.K., \& Mugo, H.W. (2010). Internal factors affecting procurement process of supplies in the public sector; a survey of Kenya government ministries. Paper presented at 5th International Public Procurement Conference was held on August 17th, 2012 in Seattle, USA.

Nzambu. J. M (2015). Determinants of procurement performance in County governments: the case of ministry of Health and emergency services, machakos, Kenya Msc research project University of Nairobi 
OECD (2011). Strengthening Partner Country Procurement Capacities - A Needs Assessment. Paris: Crown Agents.

Orodho .C. R. (2009). Element of Education and Social Sciences. Research Methods $2^{\text {nd }}$ Edition, Kanezja Publishers. New Delhi

Oso, Y. \& Onen, D. (2008). A general Guide to Writing Research Proposal and Report. Kisumu: Options Printers and Publishers.

Perry, C. (2011). Supporting access to public procurement opportunities. Research and Information Service Research Paper, 12 (1), 12-22.

Pitt, N. (2016). The private finance initiative and value for money . Journal of property

Pollitt, C., \& Bouckaert, G. (2014). Public Management Reform: A Comparative Analysis, 2nd .Oxford: Oxford University Press.

PPOA (2010). Assessment of the Procurement System in Kenya Report. A report by Public Procurement Oversight Authority, Nairobi

PPP, T. N. (2012). Testing tradition. Assessing the added value of public-private partnership.

Procurement Reform Project (2014). African Regional Workshop on Harmonization, Alignment and Results, available on http:/www.worldbankorg/ on 14th Dec.2017.

Rahman, M.M., \& Kamaraswamy, D. (2012). Risk management trends in the construction industry: moving towards joint risk management. Engineeering Construction and Architectural Managemnt.

Rambo, C. M. (2012). Procurement Reforms and Expenditure Management in Public Secondary Schools. Nairobi: DBA African Management Review Publishers.

Richard, S. W. (2013). Institutions and Organizations: Ideas and Interests. Kenya: Sage Publications.

Roodhooft, F., \& Abbeele, A. (2009). Public procurement of consulting services Evidence and comparison with private companies. International Journal of Public Sector Management, 19(5), 490- 512

Schapper, M., \& Paul, R. (2015). An Analytical Framework for the Management and Reform of Public Procurement. Journal of Public Procurement, 6(2), 45-68.

Sekaran, U. (2009). Research methods for business 4th edition. Hoboken, NJ: John Wiley \& Sons.

Seman, A., Zakua, N., \& Shoki, M. (2016). Green Supply Chain Management: A Review and Research Direction. International Journal of Managing Value and Supply Chains (IJMVSC) 3(1) 35-52.

Shirima, D. L. (2009). Value for Money Through Reduced Procurement Transaction Costs and Improved Efficiency. Tanzania Procurement Journal, 44-52. Tanzania Procurement Journal, 4 -5. 
Smith, A.K. (2011). Best practices management in the public sector. Quality Progress Publishers, $3^{\text {rd }}$ edition, Lagos, Nigeria.

Thai, K. V. (2009). International handbook of public procurement. International handbook of public procurement. Taylor and Francis Group.

Thai, K.V. (2010). Towards New Horizons in Public Procurement”. Towards New Horizons in Public Procurement Academics Press.The national council of Public-Private partnership, $4(1), 5-7$.

Thomas, A.V., Kalidindi, S.N \& Ananthanarayanan. (2013). Risk perspection analysis of BOT road project participants in India. Construction Management and Economics.

Transparency International (2010). The Kenya Public Procurement Sector Supplier Management Study Report, Nairobi: Transparency International.

Trochin, W.M.K. (2008). Research methods. Knowledge base. Kogan Page Ltd, London, UK.

UNESCO (2014). Global Monitoring Report: The Role of the Organization and Social Context of Public Procurement. http://portal.org/education.

Wanjohi, M. A. (2012). Challenges facing supplier base management in Kenya and the efforts in progress. Nairobi: Acts Press.

Wanyama, J. (2010). The Effectiveness of the Procurement Regulations in Kenya. Available on http:/www.oecd.org, on 18th Dec 2017

World Bank (2008). "Standard Bidding Documents: Procurement of Works", Washington, D.C: World Bank.

Xingxing, Z. (2012). An agency theory perspective on supply chain quality managenent. International journal of operations and production management, 4(1), 423-446. 